\title{
DEPOSITORY INSTITUTIONS AND SUSTAINABLE AGRICULTURE IN NIGERIA
}

\author{
Ihayere Oseghale ${ }^{*}{ }^{\circledR}$, Ugege Joseph ${ }^{1}$, Abu Prince 2 \\ ${ }^{1}$ National Institute of Construction Technology and Management, Uromi, Edo State, Nigeria \\ 2 Regenesys Business School, Sandton, Johannesbury, South Africa
}

DOI: https://doi.org/10.29121/granthaalayah.v8.i5.2020.123

Article Type: Research Article

Article Citation: Ihayere Oseghale, Ugege Joseph, and Abu Prince. (2020). DEPOSITORY

INSTITUTIONS AND SUSTAINABLE AGRICULTURE IN NIGERIA.

International Journal of Research GRANTHAALAYAH, 8(5), 173-178. https://doi.org/10.29121/granthaa layah.v8.i5.2020.123

Received Date: 18 May 2020

Accepted Date: 31 May 2020

Keywords:

Sustainable Agriculture

Agriculture Finance

Depository Institutions

\begin{abstract}
Aligning with Goal two of Sustainable Development Goals (SDGs2) to accomplish zero hunger by the year 2030. This research dives deeper into how Agriculture can be sustained to actualize SDGs2 through the assistance of depository Institutions. The results show that deposit money bank loans, deposit money bank loans rate, exchange rate, government expenditure and agricultural credit sector fund have pose positive effect on agricultural output, only the duo of exchange rate and agricultural credit sector fund indicate a significant impact on agricultural output at the 5\% level of significance while deposit money bank loans have a slightly positive significant effect on agricultural output at approximately $10 \%$ level of significance. This implies that across the period under investigation, deposit money bank loans, exchange rate and agricultural sector credit fund impose significant and positive contribution to agricultural output.
\end{abstract}

\section{INTRODUCTION}

Historically, beginning with early men, agriculture has been found to be vital to human development. Apart from providing some of the basic needs of man (such as food and as a source of income), agriculture supports the development of other sectors of the economy through provision of resources that serves as raw materials in the production of goods and a reliable source of government revenue (Igudia, 2010; Ajie and Ewabore, 2013; Anyanwu, Ibekwe and Adesope 2010). Agricultural sector is key to economic growth as a result of its contributory effect through provision of employment and foreign exchange earnings accumulation (Okonkwo, Nwaru, Nwokoro and Ukeje 2017). As succinctly put by Abayomi (2002) rising agricultural production is highly crucial for attainment of industrialization.

However, according to Federal Ministry of Agriculture and Rural and Development (2016), the Nigerian agricultural sector is bedeviled by two crucial problems: an incompetence to meet domestic food requirements, and an incapability to export at quality levels required for market realization. Stefan and Douglas (2014) attribute the low performance of agricultural sector to inadequate capital financing of agricultural investments. On the backdrop of these two major problems, deposit money banks have been mooted to provide succor in eliminating some of these challenges through provision of funds to farmers in a bid to boost agricultural production. Agricultural financing is

(C) 2020 The Author(s). This is an open access article distributed under the terms of the Creative Commons Attribution License, which permits unrestricted use, distribution, and reproduction in any medium, provided the original author and source are credited. 
key in food production, particularly in advanced countries (Ojiegbe and Duruechi, 2015). It is used to acquire extensive control of additional resources (Olaitan, 2006).

Thus, the aim of this paper is to empirically investigate the impact of deposit of money banks' loans on agricultural sector output in Nigeria.

\section{LITERATURE REVIEW}

Nnamocha and Eke (2015) revealed high contribution of bank credit and industrial output to agricultural output in Nigeria in the long run while in the short run only industrial output pose a significant to agricultural output. Obilor (2013) show that financing vehicle such as credit guarantee fund and government fund allocation yield positive effect on productivity. Toby and Peterside (2014) in their analysis of role of banks in agricultural financing revealed that deposit money banks and merchant banks lagged in agricultural financing. Specifically, they reported a weak correlation between deposit money bank lending and agriculture's contribution to gross domestic product. Das, Senapati and John (2009) examined the task of direct and indirect credit on agricultural production found direct credit to be statistically significant on agricultural production while indirect credit posed a significant positive impact on agricultural albeit with a year lag on agricultural output with a conclusion that despite the hiatus posed by current institutional credit delivery system, agricultural credit is provides fundamental support in agricultural production. Ammani (2012) found a positively significant relationship between credits to agricultural sector and agricultural productivity.

Ekine and Onukwuru (2018) examined the deposit money banks and agricultural Sector performance employing ECM revealed that there is no cointegration (or long run) relationship between deposit money banks credit to agricultural sector and the performance of agriculture sector in Nigeria during the period of study; deposit money banks' credit to agricultural sector (BCA) had a positive and a significant impact on Agricultural Sector performance (ASP); Interest Rate (INR) had a negative insignificant relationship with agricultural sector performance (ASP). Also, the study revealed that government expenditure on agricultural sector (GEA) had a positive insignificant relationship on Agricultural Sector performance (ASP). Consequent upon the above, it is recommended that efforts should be made by the government and private individuals to encourage or increase investment in the agricultural sector. The lending rate on loans to the agricultural sector should be reviewed and fixed at a rate that would encourage farmers to acquire loans from deposit money banks.

\section{THEORETICAL FRAMEWORK}

Commercial loan theory of liquidity also known as the real bill doctrine was developed by Adam Smith in 1776. Adam Smith use this theory to explain the bank liquidity that short-term loans advanced to finance salable goods on the way from producer to consumer are the most liquid loans the bank can make which can be represented as;

$\mathrm{SLG}=\mathrm{f}(\mathrm{STL})$

Where;

SLG = Salable goods.

$\mathrm{STL}=$ Short term loans

These are self-liquidating loans because the goods being financed will soon be sold.

The loan finances a transaction and the transaction itself provides the borrower with the funds to repay the bank. Here we incorporate lending rate.

$\mathrm{SLG}=\mathrm{f}(\mathrm{STL}, \mathrm{LNR})$

According to Adam Smith these loans are liquid because their purpose and their collateral were liquid. The goods move quickly from the producers through the distributors to the retail outlet and then are purchased by the ultimate cash-paying consumer.

Salable goods (SLG) is proxied by Sustainable Agriculture (SA), while short term loans (STL) which finances the agriculture output is represented by deposit money banks loans (DMBL), lending rate from the deposit money banks' 
lending rate towards the agriculture sector is represented by (DMBLR). Further explanation on the theory states that a deposit money banks should forward only short-term self-liquidating productive loans to business organizations. Loans meant to finance the production, and evolution of goods through the successive phases of production, storage, transportation, and distribution are considered as self-liquidating loans.

$$
S A=f(D M B L, D B M L R)
$$

\subsection{MODEL SPECIFICATION}

In line with Ekine and Onukwuru (2018), the model is specified as:

$$
\mathrm{ASP}=f(\mathrm{BCA}, \mathrm{INR}, \mathrm{GEA})
$$

Where;

ASP = Agricultural Sector Performance BCA = Deposit Money Banks' Credit to Agricultural Sector. INR = Interest Rate. GEA = Government Expenditure on Agricultural Sector

Adopting Equ. (4) to form our model, Equ. (3) is revised to include Government expenditure (GE) on agriculture, Agriculture Credit Guarantee Scheme Fund (ACGSF) and Exchange Rate (EXR). Thus, the functional form of our model is specified as:

$\mathrm{SA}=f(\mathrm{DMBL}, \mathrm{DMBLR}, \mathrm{ACGSF}, \mathrm{GE}, \mathrm{EXR})$

Where;

SA = Sustainable Agriculture DMBR = Deposit Money Banks' Credit to Agricultural Sector. DMBLR = Interest Rate ACGSF = Agricultural Credit Guarantee Scheme Fund.GE = Government Expenditure on Agricultural Sector .

Accordingly, the econometric form of the model is:

SAt $=\alpha_{0}+\alpha_{1}$ DMBLt $+\alpha_{2}$ DMBLR $t+\alpha_{3}$ ACGSFt $+\alpha_{4}$ EXRt $+\alpha_{5}$ GE $t+U t$

Where:

SAt = Output of Agricultural Sector at time ' $t$ '

DMBLt $=$ Deposit Money Banks' Loans to Agricultural Sector at time ' $\mathrm{t}$ '

DMBLRt $=$ Deposit Money Bank Loans at time ' $t$ '

ACGSFt $=$ Agriculture Credit Guarantee Scheme Fund at time ' $t$ '

EXRt $=$ Exchange Rate at time ' $\mathrm{t}$ '

$\mathrm{GEt}=$ Government Expenditure on Agricultural Sector at time ' $\mathrm{t}$ '

$\alpha_{0}$ is the constant term, $\alpha_{1}, \alpha_{2}, \alpha_{3}, \alpha_{4}, \alpha_{5}$ and $\alpha_{6}$ are co-efficient of the independent variables

Ut $=$ Error term

The aprori expectations are stated as:

$\alpha_{0}, \alpha_{1}, \alpha_{3}, \alpha_{5}, \alpha_{6}>0 ; \alpha_{2}, \alpha_{4},<0$

\section{PRESENTATION/ INTERPRETATION OF RESULT}

Table 1: Descriptive Result

\begin{tabular}{|l|c|c|c|}
\hline & Mean & Median & Std. Dev. \\
\hline SA & 7156.396 & 4589.442 & 4743.326 \\
\hline DMBL & 94.14497 & 32.1549 & 139.8422 \\
\hline DMBLR & 17.59504 & 17.54281 & 4.757259 \\
\hline EXR & 76.59172 & 57.3722 & 72.03856 \\
\hline GE & 14.5864 & 4.613742 & 18.68826 \\
\hline ACGSF & 3.059679 & 2419337 & 4.209266 \\
\hline
\end{tabular}

Source: Researcher's Computation (2019) using Stata 14

International Journal of Research -GRANTHAALAYAH 
The above table shows that on average, gross agricultural output between 1981 and 2016 is 7156.3 billion naira with a standard deviation of 4743.3 billion. Meanwhile, across the period 1981 and 2016, average deposit money bank loans are 94.14 billion naira with standard variation of 139.8 billion. Similarly, average government expenditure on agriculture is 14.58 billion naira and agricultural credit scheme fund averaged 3.05 billion naira.

Table 2: Correlation Result

\begin{tabular}{|l|c|c|c|c|c|c|}
\hline Correlation & & & & & & \\
\hline Probability & SA & DMBL & DMBLR & EXR & GE & ACGSF \\
\hline SA & 1.000000 & & & & & \\
\hline & ----- & & & & & \\
\hline DMBL & 0.893220 & 1.000000 & & & & \\
\hline & $0.0000^{* * *}$ & ----- & & & & \\
\hline DMBLR & 0.036187 & -0.048513 & 1.000000 & & & \\
\hline & 0.8340 & 0.7787 & ---- & & & \\
\hline EXR & 0.937187 & 0.816431 & 0.102523 & 1.000000 & & \\
\hline & $0.0000^{* * *}$ & $0.0000^{* * *}$ & 0.5518 & ---- & & \\
\hline GE & 0.780669 & 0.678691 & -0.005164 & 0.751293 & 1.000000 & \\
\hline & $0.0000^{* * *}$ & $0.0000^{* * *}$ & 0.9762 & $0.0000^{* * *}$ & ----- & \\
\hline ACGSF & 0.946431 & 0.874548 & -0.067633 & 0.842616 & 0.736570 & 1.000000 \\
\hline & $0.0000^{* * *}$ & $0.0000^{* * *}$ & 0.6951 & $0.0000^{* * *}$ & $0.0000^{* * *}$ & ---- \\
\hline
\end{tabular}

Source: Researcher's Computation (2019) using Stata 14

**Significant at $5 \%$ level of significance

***Significant at $1 \%$ level of significance

Correlation measures the extent or size of linear association or relationship between variables. The correlation results as reported in Table 4.2 above shows that deposit money bank loans, deposit money bank loans rate, government expenditure, exchange rate and agricultural credit sector fund have positive correlation with agricultural output. This implies that as these variables move in an upward direction, agricultural output move in the same direction.

Table 3: Unit Root Test Result

\begin{tabular}{|l|l|c|c|c|c|}
\hline Variable & Test in & Statistic & Prob. & $5 \%$ Critical Value & Decision \\
\hline SA & First Difference & -4.604 & 0.0001 & -2.975 & Stationary at First Difference \\
\hline DMBL & First Difference & -5.135 & 0.0000 & -2.975 & Stationary at First Difference \\
\hline DMBLR & Level & -3.422 & 0.0102 & -2.972 & Stationary at Level \\
\hline EXR & First Difference & -3.669 & 0.0046 & -2.975 & Stationary at First Difference \\
\hline GE & First Difference & -9.210 & 0.0000 & -2.975 & Stationary at First Difference \\
\hline ACGSF & First Difference & -8.170 & 0.0000 & -2.975 & Stationary at First Difference \\
\hline
\end{tabular}

Source: Researcher's Computation (2019) using Stata 14

**Significant at $5 \%$ level of significance

***Significant at $1 \%$ level of significance

Unit root test is a test that investigate the time series properties and ascertain the stationarity or nonstationary of a particular variable. This test has become very imperative when carrying out a study on time series variable because of the well-established knowledge that most economic time series variables are non-stationary at levels, but they tend to become stationary after first or second differencing (Iyoha 2006, Gujarati and Porter 2009).

From the above table, the stationary test shows that whereas deposit money bank lending rate is stationary at level, agricultural output, deposit money bank loans, exchange rate, government expenditure and agricultural credit fund are stationary at first difference at 5 percent level of significance. 
Table 4: Regression Result (Ordinary Least Squares)

\begin{tabular}{|l|c|c|c|c|}
\hline Variable & Coefficient & Std Error & t-statistics & Probability \\
\hline Constant & 2372.11 & 609.9028 & 3.89 & $0.001^{* * *}$ \\
\hline DMBL & 4.506391 & 2.385387 & 1.89 & $0.069^{*}$ \\
\hline DMBLR & 32.10633 & 34.03042 & 0.94 & 0.353 \\
\hline EXR & 26.54382 & 4.646073 & 5.71 & $0.000^{* * *}$ \\
\hline GE & 13.79532 & 13.03537 & 1.06 & 0.298 \\
\hline ACGSF & 510.138 & 88.65356 & 5.75 & $0.000^{* * *}$ \\
\hline & & & & \\
\hline R-Square & 0.9685 & & & \\
\hline Adj. R-Square & 0.9633 & & & \\
\hline Std. Error of Reg. & 908.95 & & & \\
\hline F-Statistic & 184.63 & & & \\
\hline Prob(f-statistic) & 0.0000 & & & \\
\hline Durbin-Watson & 1.6499 & & & \\
\hline
\end{tabular}

Source: Researcher's Computation (2019) using Stata 14

**Significant at $5 \%$ level of significance

*** Significant at $1 \%$ level of significance

The estimated model models the impact of deposit money bank loans on agricultural output in Nigeria. The study covers the period between 1981 and 2016. From the table above, the R-square indicate that 96.8\% (percent) of the variation in agricultural output is jointly explained by the control variables with $3.3 \%$ (percent) due to stochastic error term. Nonetheless, with the model adjusting for the degree of freedom, the adjusted R-square indicate that $96.1 \%$ (percent) of variation is "truly" explained by the control variables. This implies that the model has a high predictive ability. The F-statistics with an associated probability value less than 5\% (percent) level of significance indicate that the overall model is statistically significant implying that the explanatory variables jointly explain variations in the dependent variables and the adjusted R-square is statistically different from zero.

From the regression result shows that deposit money bank loans, deposit money bank loans rate, exchange rate, government expenditure and agricultural credit sector fund have pose positive effect on agricultural output, only the duo of exchange rate and agricultural credit sector fund indicate a significant impact on agricultural output at the 5\% level of significance while deposit money bank loans have a slightly positive significant effect on agricultural output at approximately $10 \%$ level of significance. This implies that across the period under investigation, deposit money bank loans, exchange rate and agricultural sector credit fund impose significant and positive contribution to agricultural output.

\section{RECOMMENDATION AND CONCLUSION}

Hence, based on the findings of this study, the following recommendations are proffer;

There should be intensified efforts by the governments and all concerned private hands to encourage investment towards agricultural sector by reviewing the lending rate on loans to encourage farmers acquire loans from deposit money banks. Going further the government can strengthen the agricultural credit guarantee scheme fund through significant budgetary allocation in order to enhance its capital base significantly by increasing its financial grants to agricultural firms and small-scale farmers and finally other factors like Climate Change should be given more attention.

\section{SOURCES OF FUNDING}

None.

\section{CONFLICT OF INTEREST}

None. 


\section{ACKNOWLEDGMENT}

None.

\section{REFERENCES}

[1] Abayomi E. (2002). Realizing the potential of Agriculture in Nigeria. CBN Bulletin, 26: 11-34

[2] Ajie H.A., and Ewabore D.B., (2013) Financial Instituions: Market and Contemporary Issues. Pearl Publishers, Port Harcourt.

[3] Ammani, Aliyu. (2012). An Investigation into the Relationship between Agricultural Production and Formal Credit Supply in Nigeria. International Journal of Agriculture and Forestry. 2. 46-52. 10.5923/j.ijaf.20120201.08.

[4] Anyanwu, S.O., Ibekwe, U.C. and Adesope, O. (2010), Agriculture Share of the Gross Domestic Product and its implication for Rural Development, International Research Journal of Applied Basic Sciences, 4(3), pp. 548 555.

[5] Das, A., Senapati, M., and John, J. (2009). Impact of Agricultural Credit on Agriculture Production: An Empirical Analysis in India. Reserve Bank of India Occasional Papers, 30(2), 75-107.

[6] Ekine O.N and Onukwuru, S. (2018). The impact of Deposit money banks credit on Agriculrural sector.

[7] Igudia, P.O. (2010). Global Food Crisis and Food Insecurity in Nigeria, Confluence Journal of Environmental Studies, 5, pp 80-97.

[8] Nnamocha, P. N. and Eke, C. N. (2015). "Bank Credit and Agricultural Output in Nigeria (1970 - 2013): An Error Correction Model (ECM) Approach”. British Journal of Economics, Management \& Trade, 10(2): 1-12, 2015, Article no. BJEMT.19884.

[9] Obilor, S. I. (2013). The Impact of Commercial Banks' Credit to Agriculture on Agricultural Development in Nigeria: An Econometric Analysis, International Journal of Business, Humanities and Technology, Vol. 3 No. 1.

[10] Ojiegbe, J.N., and Duruechi A.H. (2015). Agricultural loans, as catalyst for Food Production in Nigeria: The Problems and Prospects.

[11] Okonkwo, I.I., Nwaru, J.C., Nwokoro, C.C., and Ukeje, B.A. (2017) Differentials in adoption stages of improved cassava production rechnologies among small-holder farmers in Anambra State: Agender situation analyses: Nigeria Agricultural Journal.

[12] Olaitan, M.A., (2006). Financing for small and medium enterprises Nigeria's agricultural credit guarantee scheme fund. Journal of international Farm Management, 3(2): 1-9.

[13] Stefan D. and Douglas G. (2014). Agriculture in African Development: A Review of Theories and Strategies. CSAE Working Paper WPS/2014-22

[14] Toby, A. J. \& D. Peterside (2014). Monetary Policy, Bank Management and Real Sector Finance in Nigeria: Who is to Blame? Proceedings of the First Middle East Conference on Global Business, Economics, Finance and Banking (ME14 DUBAI Conference) Dubai, 10-12 October 2014 ISBN: 978-1-941505-16-8 Paper ID_D482. 